\title{
La falconeria a la Corona d'Aragó durant la baixa edat mitjana: estudi i edició crítica de textos
}

\section{Falconry in the Crown of Aragon in the late Middle Ages: text analysis and editing}

Antoni Mas i Miralles antoni.mas@ua.es

Universitat d'Alacant

Institut Interuniversitari de Filologia Valenciana

Entre la fi de l'Antiguitat i l'alta edat mitjana una nova modalitat de caça, la falconeria, arribava a l'Europa occidental i es difonia arreu de les terres del continent, principalment de mà dels pobles germànics. Els regnes hispànics, però, aviat van rebre la influència d'una altra tradició de caça amb ocells de presa ensinistrats, pràctica que els pobles àrabs i musulmans van portar a l'Occident europeu. A partir de la convergència d'aquestes dues tradicions -en gran mesura independents- es va desenvolupar una activitat que a la baixa edat mitjana aconseguiria la seua màxima difusió, apogeu i esplendor. Possiblement calga buscar en aquesta doble via d'entrada la riquesa de la falconeria a la península Ibèrica, com també algunes de les singularitats lèxiques, tècniques i socials, que les diverses obres suggereixen.

Durant la baixa edat mitjana, aquesta activitat es presenta perfectament consolidada a tota Europa, on ha perdut el caràcter pràctic o utilitari que possiblement tingué en els seus orígens o primeres etapes de desenvolupament $i$, de fet, el valor material de les preses capturades es presenta més aviat com una cosa residual. Aquesta modalitat de caça -juntament amb la munteria- esdevé un element fonamental en la formació de l'aristocràcia, i alhora constitueix un dels elements principals d'oci i delit. Aquesta associació entre la falconeria i la noblesa va fer que arribara a convertir-se en símbol de poder, trobant-hi la burgesia una de les formes d'aproximació i imitació a l'estrat més alt de la societat. La simbologia del caçador i l'au de presa va anar molt més enllà que la de representar el poder, i tots dos es convertiren en símbol de diverses qualitats humanes, tant positives com negatives. Alguns d'aquests valors simbòlics de la falconeria van ser explotats per l'Església, que va recórrer als ocells i als caçadors per fer que el missatge religiós fora comprés per un major nombre de creients que, sens dubte, estaven familiaritzats amb els ocells de presa i amb la pràctica de la caça. 
Antoni Mas i Miralles. La falconeria a la Corona d'Aragó durant la baixa edat mitjana: estudi i edició crítica de textos

De fet, la presència social d'aquesta modalitat de caça es posa de manifest en la gran quantitat de persones implicades d'una o altra forma, com ara aquelles encarregades de vigilar els nius, de capturar les aus i de transportar-les fins a la seua destinació; els camperols i carnissers, que venien gallines, coloms i altres carns per a aliment de les aus; els camperols que es trobaven als caçadors en les seues partides de caça (en ocasions provocant danys en els camps o patint l'atac en els seus corrals); els fusters $i$ altres artesans que elaboraven els diversos instruments requerits en aquesta modalitat de caça; els mercaders que portaven aus de diversos punts d'Europa i de la Mediterrània per a la venda; o els capitans dels navilis, familiaritzats amb el transport d'aquests animals. Tot això, sense comptar amb els falconers, professionals al servei de reis i senyors, encarregats d'ensinistrar i cuidar les seues aus.

Cal assenyalar que, malgrat l'escassa informació que proporcionen les fonts, aquestes ens permeten també intuir l'interés de les dones per la falconeria, a més de la intervenció en diferents aspectes d'aquesta art. Així, el seu interés queda testimoniat per la presència d'obres de falconeria en les biblioteques d'algunes reines. També trobem a les dones com a proveïdores de medicaments per a guarir ocells i, fins i tot, atenent l'encàrrec de la cura d'algun falcó del rei. D'aquesta manera, es pot afirmar, sense por d'exagerar, que els ocells de caça constituïen un element quotidià i familiar per a la societat baixmedieval, fet que es posa de manifest en la gran presència de les aus de caça i dels caçadors en les arts decoratives i en la literatura, per exemple.

Una altra prova més de la importància que aquesta activitat va tenir en la societat medieval va ser l'origen i l'enorme proliferació d'un gènere literari específicament relacionat: els tractats de falconeria. Els 500 manuscrits d'aproximadament 150 tractats que han arribat fins als nostres dies constitueixen una de les principals fonts per a l'estudi de la falconeria a l'edat mitjana. El valor d'aquests documents és fabulós. El seu contingut inclou aspectes ornitològics, cinegètics i, sobretot, mèdics, i posen de manifest que la cura de les aus constituïa una seriosa preocupació per als caçadors, i que aquesta no era una activitat autònoma, sinó que es relacionava estretament amb altres pràctiques mèdiques, especialment la medicina humana. La primerenca vernacularització d'aquest gènere tècnic al voltant del segle XIII presenta, sens dubte, un gran interés per a l'estudi de les llengües i literatures romàniques, a més de ser un aspecte de gran rellevància per a la història social de la ciència.

La documentació d'arxiu com a font per a estudis relacionats amb la falconeria, sobretot d'alguns aspectes socials, gairebé no s'ha explotat de forma sistemàtica. Entre aquests estudis destaca el realitzat per Oggins (2004) a Anglaterra, amb un buidatge exhaustiu de documentació que ha permés, entre altres qüestions, un estudi prosopogràfic dels falconers reials. En l'àmbit de la Corona d'Aragó cal destacar l'abundant documentació recopilada per Bover i Rosselló (2003) dels arxius balears, que ha posat de manifest algunes singularitats de la falconeria al regne de Mallorca, com l'existència de professionals que ensinistraven falcons per encàrrec per a diferents persones -els coneguts com a afaitadors de falcons-, o la pràctica d'aquesta caça per part de membres d'estaments menys elevats de la societat, fet que es relaciona amb la influència musulmana. Alguns sondejos realitzats pels investigadors d'aquest projecte en altres arxius històrics de la Corona d'Aragó, i

SCRIPTA, Revista internacional de literatura i cultura medieval i moderna, núm. 17 / juny 2021 / pp. 232 - 236 ISSN: 2340-4841 ·doi:10.7203/SCRIPTA.17.20913 
Antoni Mas i Miralles. La falconeria a la Corona d'Aragó durant la baixa edat mitjana: estudi i edició crítica de textos

la publicació de fonts molt valuoses procedents de la Cancelleria reial (Bofarull 1880-1885) han permés constatar-hi que la falconeria es trobava ben present en aquests territoris i que es tracta d'una documentació amb un gran potencial per a la investigació d'aquesta activitat.

També la presència de la falconeria en la literatura medieval ha estat objecte d'estudi en diverses ocasions. Podem destacar el treball de Van den Abeele sobre la falconeria en la literatura francesa medieval (1990) o el de Horobin en la literatura anglesa (2004), entre d'altres. En l'àmbit català, per ara comptem només amb estudis molt puntuals de passatges concrets o generals, sobre els animals en la literatura catalana. Aquesta revisió de la falconeria a l'edat mitjana i dels estudis que se'n desprenen permet contextualitzar adequadament el projecte de recerca que fonamenta el dossier que el lector té ara a les mans, i que consistiria en l'estudi de la falconeria a la Corona d'Aragó atenent els múltiples aspectes que conformaven aquesta activitat: pràctiques i sabers (ornitologia, caça, medicina), tractats mèdics, simbologia, cultura material, societat (caçadors, falconers, afaitadors de falcons $\mathrm{i}$ totes les persones implicades directament o indirectament en l'activitat), lèxic tècnic, regulacions associades a la caça amb aus, etc.

La Corona d'Aragó no va ser una excepció en tots aquests aspectes relacionats amb la falconeria. La documentació d'arxiu ha posat clarament de manifest que aquesta modalitat de caça estava entre les activitats preferides de molts monarques. En aquest sentit, cal tenir en compte que aquesta afició va arribar a tal extrem que al rei Joan I d'Aragó li va valer el sobrenom del Caçador. No menys significativa resulta la important i detallada organització del personal dedicat a la falconeria que Pere el Cerimoniós va establir a les seues Ordinacions (Gimeno / Gozalbo / Trenchs 2009). Precisament una personalitat de la rellevància d'Ausiàs March va ocupar el càrrec de falconer major establert en aquestes Ordinacions, al servei d'Alfons el Magnànim. I, de fet, la seua afició a la caça i la seua experiència en aquesta art es fa explícita en la seua obra literària. També religiosos com Francesc Eiximenis o Vicent Ferrer van considerar necessari o apropiat referir-se a la falconeria, les aus i els caçadors, per dirigir les seues crítiques, o com a elements apropiats per construir símils i metàfores en els seus sermons (Ferragud / Olmos 2012). Tot això no és sinó una prova més de la gran presència d'aquesta activitat en la societat baixmedieval de la Corona d'Aragó. I és que, igual que en altres regnes $i$ territoris europeus, una activitat tan present en la societat no podia faltar tampoc en la literatura produïda en llengua catalana.

Fins al present, l'estudi de la història de la falconeria a Europa és força heterogènia, tant pels aspectes investigats com per les fonts emprades. Sens dubte, l'edició crítica dels tractats ha estat un de les activitats més desenvolupades i s'ha completat en un grau força elevat en alguns àmbits, com el llatí, el portugués o el castellà. A l'extrem oposat es troben els tractats italians de falconeria, que a penes han merescut l'interés d'alguns investigadors. Cal destacar el fet que és precisament en aquesta llengua en què es van escriure alguns dels més importants tractats de falconeria de la Corona d'Aragó. Quant als tractats catalans de falconeria que s'han conservat, el procés d'edició es troba aproximadament en un punt mitjà, i resten encara dos importants manuscrits per ser estudiats i editats. 
No obstant això, l'edició crítica d'aquestes obres s'ha realitzat, habitualment, des de l'àmbit de la filologia, fet que ha suposat també que gran part dels continguts d'aquestes obres romanguen sense explotar. Més recentment, des de la història de la ciència s'ha començat a investigar els continguts mèdics dels tractats de falconeria castellans, posant-se de manifest importants relacions amb la medicina humana, fet que permet constatar la fonamentació científica en la filosofia natural i el galenisme de la cura de les aus a la baixa edat mitjana (Olmos 2016).

El monogràfic que ara presentem és el resultat de dos anys d'investigació que, amb l'aixopluc d'un projecte AICO de la Generalitat Valenciana (2019/255), s'ha portat a terme per un equip interdisciplinar en el qual especialistes en arxivística i documentació, en història i en filologia analitzem els diferents tipus de documents que ens aporten informació sobre aquesta activitat tan característica de la societat medieval. Fruit d'aquest treball són els cinc articles que presentem ara. En primer lloc, Carmel Ferragud i Ricardo Olmos editen el tractat de falconeria medieval obra del vescomte de Rocabertí. A continuació tenim el treball de Marinela Garcia, amb l'edició del Llibre dels ocells de caça, o Flors de les receptes medicinals per a ocells de caça. En tercer lloc, el treball d'Antoni Mas ofereix una edició del Tractat de medicina per tots els ocells de caça, acompanyada d'una anàlisi lèxica dels mots més destacats. Després, Roser Melchor s'encarrega de l'edició d'un text italià però que s'adscriu als textos elaborats en la cort napolitana dels reis d'Aragó, la Hopera de citraria de falcone pellegrine et gentile d'Alfonso Caracciolo, que presenta la singularitat d'ocupar-se fonamentalment dels aspectes cinegètics propis. Finalment, Carmel Ferragud, Ricardo Olmos i Vicent Bataller són els responsables de l'estudi i l'edició d'un procés judicial del segle xiv que té lloc a Llucmajor (illes Balears) sobre l'apropiació d'un falcó. Tot i tractar-se d'un text judicial, ens permet conéixer de primera mà la importància i el valor de posseir un animal d'aquestes característiques i tot el que representava per a la societat mallorquina de l'època.

Com ja hem comentat, són cinc treballs sobre textos de falconeria inèdits, fets des de perspectives disciplinàries diferents, on es conjumina la filologia, la història de la ciència i la tecnologia, amb els quals pretenem aconseguir una aproximació tan completa com siga possible al desenvolupament d'aquesta activitat tan característica de l'edat mitjana i amb un impacte important en la societat, la història de la cultura i la literatura. Amb aquesta publicació volem superar les limitacions que els enfocaments unilaterals han tingut fins a la data i que, en el millor dels casos han limitat els resultats de la investigació, i en el pitjor d'ells, han portat a interpretacions errònies o equívoques. Tots aquests treballs d'edició no culminen ací, ja que és la nostra voluntad continuar en aquesta línia d'investigació i d'estudi. 


\section{Antoni Mas i Miralles. La falconeria a la Corona d'Aragó durant la baixa edat mitjana: estudi i edició crítica de textos}

\section{Bibliografia}

Bofarull, M. de (1880-1885) «[Documentos venatorios del] Archivo de la Corona de Aragón», La Ilustración Venatoria, 3 (1880), 105-106, 114, 122, 130, 142-143, 150, 247 i 254-255; 4 (1881), 86, 94, 142 i 190; 5 (1882), 46, 100 i 150; 7 (1884), 38, 151 i 180; i 8 (1885), 6, 14, 102, 110, 117 i $151(1880-1885)$.

Bover, J. / Rosselló, R. (2003) La Falconeria a les Balears, s. XIII-XV, Impremta Roig, Campos (Mallorca).

Ferragud, C. / Olmos, R. M. (2012) «La cetrería en los ejemplos, símiles y metáforas de san Vicente Ferrer», Anuario de Estudios Medievales, 42/1, pp. 273-300.

Gimeno, F. M. / Gozalbo, D. / Trenchs, J. (eds.) (2009) Ordinacions de la Casa $i$ Cort de Pere el Cerimoniós, València, Universitat de València.

Horobin, D. (2004) Falconry in Literature. The Symbolism of Falconry in English Literature from Chancer to Marvell, Hancock House.

Oggins, R. S. (2004) The Kings and Their Hawles. Falconry in Medieval England, New Haven, Yale University Press.

Olmos, R. M. (2016) Los cuidados de las aves de caza. Estudio de la medicina de las aves a partir de los tratados castellanos de cetrería (siglos XIII-XVI), tesi de doctorat de la Universitat de València, València.

Van den Abeele, B. (1990) La fauconnerie dans les lettres françaises du XIIe au XIVe siècle, Lovaina, Leuven University Press. 